\title{
International legal barriers to Canada's marijuana plans
}

\author{
Steven J. Hoffman JD PhD, Roojin Habibi MSc
}

I $\mathrm{n}$ a speech to the United Nations (UN) General Assembly on Apr. 20, 2016, Canadian Health Minister Jane Philpott reiterated her government's electoral promise to legalize marijuana, including for recreational use. ${ }^{1}$ Legislation will be introduced in spring 2017. Although this announcement has been widely celebrated in the public health community, the legislation will almost certainly violate the UN drug-control conventions that Canada is legally obliged to follow.

The federal government should immediately take proactive steps to seek a reservation to the marijuana provisions of these treaties and/or to initiate their renegotiation in light of its legalization plans. If these diplomatic efforts fail, Canada must formally withdraw from these treaties to avoid undermining international law and compromising its global position.

For decades, the world has collectively prohibited or controlled access to some drugs including marijuana through three international treaties: the 1961 Single Convention on Narcotic Drugs, the 1971 Convention on Psychotropic Substances, and the 1988 Convention Against Illicit Traffic in Narcotic Drugs and Psychotropic Substances. Illicit substances are categorized by the World Health Organization in one of four schedules according to their dependency-inducing potential. Schedule I substances are subject to the most stringent control measures; these include marijuana, although this categorization is currently under review.

Particular social, economic and political interests shaped the global drug-control regime we have today. The preamble to the Single Convention on Narcotic Drugs states that its focus is the "health and welfare of mankind," and that "addiction to narcotic drugs constitutes a serious evil for the individual and is fraught with social and economic danger." To this effect, Article 4(c) of the convention limits "exclusively to medical and scientific purposes the production, manufacture, export, import, distribution of, trade in, use and possession" of illicit substances, and Article 36(1a) requires state punishment for their possession, production, sale and delivery. Article 3(2) of the Convention Against Illicit Traffic in Narcotic Drugs and Psychotropic Substances specifically criminal- izes possession of drugs, even if just for personal consumption (Appendix 1, available at www.cmaj. ca/lookup/suppl/doi:10.1503/cmaj.160369/-/DC1).

Legalization of marijuana has been debated in Canada for as long as the UN drug-control conventions have prohibited it. Motivated by the sharp rise of criminal offences involving marijuana in the 1960s and 1970s, the Canadian government commissioned several reports on the drug's legalization. In 1972, the Le Dain Commission of Inquiry into the Non-Medical Use of Drugs concluded that Article 36 of the Single Convention on Narcotic Drugs obliges Canada to make possession of marijuana a punishable offence. ${ }^{2}$ Three decades later, the Senate Special Committee on Illegal Drugs suggested that possessing small quantities of marijuana could be decriminalized if the requirement of the Convention Against Illicit Traffic in Narcotic Drugs and Psychotropic Substances to criminalize "possession" applied solely to possession for trafficking. ${ }^{3}$ The International Narcotics Control Board does not share this view. ${ }^{4}$

Countries do have some flexibility in implementing the UN drug-control conventions. For example, all three conventions allow deviations if required by a country's constitution. Bolivia leveraged this exception by changing its constitution in 2009 to give its citizens the explicit right to use, produce and sell coca leaf, which nevertheless attracted criticism from the International Narcotics Control Board as an "unprecedented step" that was "contrary to the fundamental object and spirit of the Convention." 4

Several countries have found workarounds to comply with the letter of these international

\section{KEY POINTS}

- The Canadian government's plan to legalize marijuana contravenes its existing international legal obligations from United Nations (UN) drugcontrol conventions.

- Canada can learn from the varied approaches used by other countries to control marijuana, but no existing model is perfect and most do not comply with international laws.

- If committed to legalizing marijuana, Canada may be justified in withdrawing from the UN drug-control conventions, both to protect the rule of international law and to avoid any public health harms that the government believes these conventions cause. 
laws. Portugal, for instance, diverts drug offenders away from typical criminal punishments, such as prison sentences, toward mandatory education classes, treatment sessions and fines. ${ }^{5}$ The Netherlands - famous for its cannabis "coffeeshops" - continues to criminalize marijuana possession but does not enforce this law against people with small quantities. ${ }^{6}$

Other jurisdictions have legalized marijuana in ways that clearly violate the UN drug-control conventions. In 2013, Uruguay became the first country to pass legislation allowing the production, sale and consumption of marijuana for commercial and recreational purposes. ${ }^{7}$ In the United States, Colorado and Washington have similarly created legal markets for marijuana under state laws, ${ }^{8}$ leaving the country in noncompliance with its international legal obligations despite the intentions of its national government. This situation arises from the unique constitutional division of powers in the United States that gives individual states primary control over criminal matters. In Canada, the federal government controls such policy.

Although efforts to depenalize, decriminalize and even legalize marijuana could be helpful for public health if done right, ${ }^{9,10}$ these approaches violate the $\mathrm{UN}$ drug-control conventions, at least in spirit if not also in the letter of these laws. The spirit of international laws matters because the 1969 Vienna Convention on the Law of Treaties specifically requires countries to interpret conventions in light of their "object and purpose" - lest all international laws unilaterally be made void of any real meaning. ${ }^{11}$ Canadians may be less concerned with international laws when they are about drugs, but they probably do care when these laws govern genocide, nuclear disarmament or human rights. Canada cannot pick and choose which international laws to follow without encouraging other countries to do the same.

Canada can learn from the varied approaches used by other countries to control marijuana, but none of the decriminalization or legalization models are perfect and most do not comply with international laws.

If committed to this policy direction, Canada is faced with three legal paths: (1) changing its constitution; (2) convincing enough countries to allow a Canadian reservation or to revise the drugcontrol conventions; or (3) formally withdrawing from the treaties. Convincing the 32 countries with death penalties for drug smuggling to reconsider the strict UN drug-control treaties seems as politically possible as adding a constitutional right to smoke marijuana into the Canadian Charter of Rights and Freedoms. ${ }^{12}$

This means the third path is likely the only feasible legal option. Formally withdrawing from outdated treaties like these is a country's sovereign right. It may also be a moral duty if the government believes the conventions' required policies are harmful.

What should be avoided at all costs is the illegal path, which is to legalize marijuana in a way that violates Canada's international legal obligations. That would be unacceptable, unfair and unjust to all.

\section{References}

1. Philpott J. Statement from the Minister of Health on the United Nations General Assembly Special Session (UNGASS) on the World Drug Problem. Ottawa: Health Canada; 2016. Available: http://news.gc.ca/web/article-en.do?nid=1054409 (accessed 2016 May 4).

2. Le Dain G. Commission of Inquiry into the Non-Medical Use of Drugs. Ottawa: Government of Canada; 1972.

3. The International Legal Environment. In: Report of the Senate Special Committee on Illegal Drugs: cannabis. Ottawa: Senate of Canada; 2002. p. 439-68.

4. Report: International Narcotics Control Board for 2011. Vienna (Austria): United Nations International Narcotics Control Board; 2012.

5. Goulao J. A public health approach as a base for drugs policy: the Portuguese case. Vienna (Austria); 2015. Available: www.unodc. org/documents/ungass2016//Flyers/SideEvent_Portugal_20Apr16_ Flyer.pdf (accessed 2016 May 4).

6. Goetz W. Towards a public health approach to drug use in the European Union. Vienna (Austria); 2015. Available: www.unodc .org/documents/ungass2016//CND_Preparations/Reconvened58/ EMCDDA.pdf (accessed 2016 May 4).

7. Decreto del 6 de mayo de 2014: Reglamentación de la Ley 19.172 sobre marihuana y sus derivados. Montevideo (Uruguay): Republica Oriental del Uruguay; 2014.

8. Hawken A, Caulkins J, Kilmer B, et al. Quasi-legal cannabis in Colorado and Washington: local and national implications. Addiction 2013;108:837-8

9. Kahan M, Srivastava A. New medical marijuana regulations: the coming storm. CMAJ 2014;186:895-6.

10. Spithoff S, Spithoff A. Cannabis legalization: adhering to public health best practice. CMAJ 2015;187:1211-6.

11. Vienna Convention on the Law of Treaties. Vienna (Austria): United Nations; 1969.

12. Which countries have the death penalty for drug smuggling? The Economist [London] 2015 Apr. 28.

Affiliations: Global Strategy Lab (Hoffman, Habibi), Centre for Health Law, Policy and Ethics, Faculty of Law, University of Ottawa, Ottawa, Ont.; Department of Global Health and Population (Hoffman), Harvard T.H. Chan School of Public Health, Harvard University, Boston, Mass.; McMaster Health Forum (Hoffman), Department of Clinical Epidemiology and Biostatistics, McMaster University, Hamilton, Ont.

Contributors: Both authors wrote the commentary, gave final approval of the version to be published and agreed to act as guarantors of the work. 